ҒTAMP 17.71.07

\title{
Тұрысбек P.,
}

Л.Н. Гумилев атындағы Евразия ұлттық университетінің профессоры, ф. ғ. д., Қазақстан, Нұр-Сұлтан қ., e-mail: rst58@mail.ru

\section{TYPКІ ӘАЕМІ ЖӘНЕ «МАНАС» ЭПОСЫ}

\begin{abstract}
Мақалада «Манас» эпосының тақырыптық мәні, уақыт пен кеңістік сипаты, көркемдік-рухани байлығы және зерттелу тарихы сөз етіледі. Сондай-ақ, «Қазақ, қырғыз халықтарының арасындағы эпикалық, дәстүр байланысы мәселесі де фольклортану тұрғысынан қарастырылады. Эпикалық Аәстүр және қазақ-қырғыз фольклортану мәселелеріне үлес қосқан жазушы, әдебиеттанушы, зерттеушілердің шығармашылығы да жеке жеке сөз етіліп кеңінен сөз болады.

Түйін сөздер: әдебиет, көркемдік, уақыт, кеңістік, тарих, тақырып, тіл, эпос.
\end{abstract}

Turysbyek R.,

Doctor of Philological Science, Professor of L. Gumilyov Eurasian National University, Kazakhstan, Nur-Sultan, e-mail: rst58@mail.ru,

Turkish world and the epic «Manas»

This article discusses the essence of the epic «Manas», time and space, artistic and spiritual wealth and history of research. Also, the problem of epic tradition between the Kazakhs and the Kyrgyz peoples is considered in terms of folklore. Writers, literary critics and researchers who contributed to the problems of epic tradition and Kazakh-Kyrgyz folklore were also widely discussed.

Key words: literature, art, time, space, history, theme, language, epic.

Турысбек Р.,

А. ф. н. профессор Евразийского национального университета им. А.Н. Гумилева,

Казахстан, г. Нур-Султан, e-mail: rst58@mail.ru

Турецкий мир и эпос «Манаса»

В этой статье рассматривается сущность эпоса «Манас», времени и пространства, художественно-духовное богатство и история исследований. Также проблема эпической традиции межАу казахами и кыргызскими народами рассматривается с точки зрения фольклора. Писатели, митературоведы и исследователи, которые внесли свой вклаА в проблемы эпической традиции и казахско-кыргызского фольклора, также широко обсуждались.

Кмючевые слова: ^итература, искусство, время, пространство, история, тема, язык, эпос.

\section{Kipicпe}

Қазіргі кезеңде халықтар арасындағы байланыс пен сабақтастықтың маңыз-мәні бұрынғыдан да артып, жаңа бағыт, кең өріс алып келеді. Қоғамдық-әлеуметтік арналардан өзге, мәденигуманитарлық салалар да тиісінше байланысықпалдастық тұрғыдан нығайып, жауапкершілік жүгі артып, жаңашылдық пен жасампаздық бағыттар арқылы жүйелі ағыс құрап, өрісі мен өресін, өнеге-ұлағатын да кеңейтіп жатқаны анық. Бұл ретте, сөз жоқ қазақ-қырғыз халықтары тамырлы тарихымен, бауырластық қарымқатынас пен мәдени-рухани жағынан да өзара байып, барыс-келіс күшейе түскені әр тараптан айқын аңғарылады. Арғы-бергі тарихтағы ортақ мұраттар, елдік ұстаным мен руханият ісіндегі асыл арналар да қазақ-қырғыз қарымқатынасын, байланыс-сабақтастық сипаттарын, кеше-бүгін көріністерін кеңінен танытады. 
Қазақ-қырғыз халықтарының әдеби байланысын еске алғанда, сөз жоқ бірқатар ортақ мұрат пен өз ара үндестік, сабақтастық сырларына көз жеткізер едік. Бұл реттен алғанда, әрине «Қазақ фольклористикасы» атты ұжымдық еңбектің айрықша маңызы бары анық. Әрі онда халық әдебиеті үлгілері, қалыптасуы мен даму жолдары, жиналуы мен зерттелу тарихы кеңінен қарастырылады (Бекхожин, 1981: 298).

Сондай-ақ, атап айтқанда: «Қазақ, қырғыз халықтарының арасындағы эпикалық дәстүр байланысы мәселесі де фольклортануда кезек күтіп тұрған тақырыптың бірі. Туысқан халықтың ұлы эпосы - «Манасты» зерттеуге XIX ғасырда Шоқан Уәлиханов салған із совет заманында жалғаса түсті, М. Әуезов, Ә. Марғұлан еңбектері манастанудың жаңа беттерін ашты» (Қасқарбасов, 2009: 23).

Бұдан басқа, халық әдебиеті нұсқаларында асыл сөзді ардақ тұтып, ел мүддесін асқақтата жырлаған - Сүйінбай, Жамбыл, Кенен т.б. «Манас» эпосын басқа да жыр үлгілерін кеңінен толғап, жеткізгенін айтқан жөн.

Қазақ ағартушысы һәм ғалымы Ш. Уәлиханов, әсіресе Орта Азия халықтарының фольклорын, оның ішінде қырғыз халқына қатысты - «Жоңғария очерктері», «Қырғыздар туралы жазбалар», «Ыстықкөлге сапар» сынды сапарнама-күнделіктерінде аңыз-әңгіме, ертегімиф, ән-өлең мәтіндерін, ақындық өнерде эпикалық жыр үлгілерін өмір мәні мен тарихи шындық тұрғысынан қарастырып, тарихиэтнографиялық шолулар мен терең тұжырымдар жасайды. Ал, «Манас» эпосының табиғатын, тарихы мен мазмұнын,кең көлемде қарастырып, біліми-ғылыми тұрғыдан негіздеп, терең мәнді қорытындылар жасап, классикалық сипатта баға береді. Осы реттен келгенде, әрине атаған жөн: «Манас» - бұл энциклопедия, халықтың бір белгілі батыры айналасына, Манас төңірегіне, бір уақытқа жинақталған барлық ертегілерінің, хикаяларының, аңызәңгімелерінің, географиялық, діни, ақыл, адамгершілік түсінігінің қосындысы. «Манас» - тұтас бір халықтың шығармасы, тереңнен нәр алып ұзақ замандарда дамыған халықтың эпосы, сахараның «Иллиадасы»,- деп ғылыми адалдық пен тарихи шындықты негіз еткен терең мәнді тұжырым жасайды (Валиханов, 1985: 367).

Осы тұрғыдан келгенде: «...қырғыз халқының эпосы «Манас» жырының үлкен бір бөлігін жазып алуы, орыс тіліне аударуы, ең алғаш эпостың жалпы бітімі, мәдени мәні, ерекшелігі туралы беделді пікір айтуы нағыз ғылыми ерлік... «Манастың» Шоқан жазып алған бөлігін ағылшын профессоры А.Т. Хатто латын әрпімен жариялап, қатарына ағылшын аудармасын берген. Мұның өзі қазақ ғалымы бастаған істің жалғастық тауып келе жатқанын сипаттайды... Шоқанның «Манас» текстін ескі қадым жазуының мүмкіндігі толық пайдаланып, барыншы ғылыми адалдық сақтап еңбек еткені ешқашан бағасы кемімейтін жұмыс. Шоқан жазып алған «Көкетайдың асы» кейінгі кезде қырғыз тілінде де жарияланды, қазақ ғалымының эпосты хатқа түсіру принциптеріне талдау берілді. Бұл зерттеу архивтік түпнұсқа негізінде биік ғылыми методологиялық деңгейде жүргізілген» (Садырбаев, 1988:66-67).

Бұл, біздіңше еске алып, әрдайым назарда ұстап, зерттеу мен зерделеу ісінде, ғылыми ұстанымда басшылыққа алатын маңызды жәйттердің бірі.

Бір ғана руханият арнасы мен осы бағыттағы өрнекті өрістерге ден қойсақ, қырғыз халқының айбыны мен айдынын аңғартатын басты мақтанышы - «Манас» эпосының зерттелу тарихынан-ақ көп жайларға қанығар едік. Осы орайда, Ш. Уәлиханов, С. Сейфуллин, М. Әуезов, С. Мұқанов, Қ. Жұмалиев, Е. Ысмайылов, Б. Кенжебаев, Ә. Марғұлан, Р. Бердібаев, М. Жолдасбеков, Ж. Бейсенбаев т.б. ізденіс мұраттары, эпос пен оны айтушыларға қатысты көзқарас, еңбектері маңыз-мәнін әлі де жойған жоқ. Бұл ретте, сөз жоқ ф.ғ.д., профессор М.Жолдасбековтің бағалаулары мен көзқарастарының негізі бар: «...Шоқанды эпос зерттеушісі ретінде оның «Манас» жайындағы еңбектерінен («Жоңғария очерктерінде», «Ыстықкөл сапарларының күнделігінде», «Қырғыздар жайында») анық танимыз. Екінші жағынан, мұның өзін ғалымның жалпы эпос жайындағы зерттеулерінің биігі әрі қорытындысы деуге болар еді.

... «Манасты» бүтін халық өмірінің шежіресі, бүкіл халықтың ақыл-ойының көрінісі ретінде бағалайды.

... Көлемі жағынан «Илиаданың» өзінен асып түсетін - «Манас» жырын алғаш хатқа түсіріп, жариялап, «Манастану» іліміне із салған Шоқан дейтін болсақ, совет дәуірінде сол ілімді негіздеген тағы да қазақ ғалымы Мұхтар Әуезов екендігін әрқашан да мақтанышпен айта аламыз. Бұл ғылыми ортада әлдеқашан мойындалған ақиқатты әрі куанышты шындық» (Жолдасбеков, 1990: 294). Бұл арғы тарихтың ақиқатты жайттарының бірі болса, кеше мен бүгінді байланыстыратын дереккөздері, тарихи-әдеби һәм мәдени-рухани арналарда ортақ мақсат- 
мұраттарға негізделген шынайы шындықтардың бары белгілі.Қысқа шегініс жасасақ, БҰҰ шешімімен «Манас» эпосының 1000 жылдығы (1995) кең көлемде аталып, әр алуан бағытта ісшаралар өтті. Бұл Қырғыз мемлекетімен бірге түркі халықтары үшін де маңызы жоғары әрі мәдени-рухани мәні де айрықша құбылыстардың бірі болды. «Манас» эпосының идеясы халықтың рухын көтерді. Бірлігі мен ұлтаралық hәм қоғамдық келісімді арттыра түсті (Ибраимов, 2018:282). Асылы, «Жазушылар - жауапты ойдың адамдары» (Әуезов, 1969:411).

Осы орайда, әлем әдебиетінің көрнекті өкілі, қырғыз халқының даңқты перзенті Шыңғыс Айтматов «Манас» эпосын әр кез-ақ мадақ етіп, ондағы елдік-ерлік рухты жоғары қойды. Тіпті, «Манас» ұлттық және жалпыадамзаттық құндылығы мол, әрі әдеби-тарихи негізі бай тағылымды туынды. Бастысы, қырғыз халқының әлемдік мәдениетке қосқан сүбелі үлесі дегенді айтып-жазып жүрді. Осы орайда, көрнекті һәм танымал тұлға Ш. Айтматовтың: «...Өз басым өзге елге сапарға шығып, өзге жұрттың табалдырығын аттай қалсам, әрқашан қасиет тұтып, өзіммен бірге алып жүретін екі түрлі ұлттық асылым бар: бірі - «Манас», екіншісі - Мұхтар Әуезов»»» дегенінде айрықша мақтаныш, берік сенім мен терең ғибрат та бар. Әрі мұның да өзіндік мәні, негізі мен заңдылықтары да бар еді. Ойға алсақ, анығында Қырғызстанда «Манастану» ғылымы қалыптасқаны анық. Әр жылдары, атап айтқанда 1980-1985 жылдары С. Оразбақов пен С. Қаралаевтың жырлауымен «Манас» эпосының 9 томдық академиялық басылымы жарық көрді. «КСРО халықтарының эпосы» атты одақтық серия негізінде - қырғыз, орыс тілдерінде жарық көрді. «Ел әдебиеті» сериясымен 14 том болып басылды» (Дәдебаев, 207:135,141).

\section{Талдау}

Қырғызстанның экс-президенті, академик А. Ақаев «Қырғыз мемелекеттігі және «Манас» халық эпосы» атты еңбегінде пассионерлі қызығушы күш әрі Мемлекеттік идеясының негізі, ар мен адамгершілік кодексі төңірегенде қарастырылды. Манастың жеті өсиеті назарға алынады: Бірлік пен ұйымшылдық; Ұлтаралық келісім, достық, ұлттық ар мен патриотизм; Қажырлы ерен еңбек пен білім арқылы гүлдену мен өркендеу; Гуманизм, кеңпейілділік, сабырлық; Табиғатпен үйлесім; Қырғыз мемлекетін нығайту және қорғау (Ақаев, 2003:229,237).
Бұл тұстардан, сөз жоқ «Манас» батырлық эпосы, арғы тарихтың құпиялары мен сырсипаттары кең түрде танылады. Әрі кітап авторы ежелгі заман мұраларына, батырлық эпостар мен тарихи оқиғалар мәніне, ғасырлар қойнауынан қазіргі кезең аралығындағы сыртқыішкі жағдайларға, Қырғыз өлкесі Темірлан, Қоқан дәуіріне, адам құқықтары мен шекара мәселесіне де ден қояды. Бастысы, «Манас» эпосы мен қырғыз мемлекеттілігі мәселесіне кең орын береді. Кеше мен бүгін байланысына, тағылымды тұстарына ден қояды.

Орайлы тұста еске алсақ, Қырғыз мемлекетінің бастауында тұрған Ә. Сыдықов, Ж. Әбдірахманов, Т. Айтматов, И. Айдарбеков, Б. Исакеев, Қ. Тыныстанов т.б. қоғамдықсаяси ахуалға, мәдени-рухани арналарға сергек қарады. Ел-жердің тағдыр-талайына араласып, ұлттық мемлекет құру жолында ерен еңбек етті. Айталық, бір ғана Қасым Тыныстанов мемлекет қайраткері деңгейіне көтерілуімен қатар, ұлт руханиятының барша саласында (мысалы, ақын, ағартушы, әдебиеттанушы һәм драматург) айқын бағыты мен бедерлі бейнесін, өшпес ізін қалдырды (Жаныбеков, 2003:292). Әсіресе, ағарту саласының басында тұрды. Жаңа алфавитті қабылдау ісіне белсене араласты. Бакуде өткен (1926) Бүкілодақтық түркологиялық конференцияға қатысып, арнайы баяндама жасайды. «Біз не үшін латын әліпбиіне өтуден жасқанамыз» атты маңыз-мәні жоғары, өзектілігі айқын мақала жазды. Бұдан басқа, «Алфавитті алмастыру жөніндегі сұраулар» (1925), «Жаңа алфавит құрылымының негізгі қағидалары» (1926), «Ана тілі - мәдени құрылыстың тірегі» (1934) т.c.c. мақалаларында ұлт пен ұрпақ, отан мен отбасы алдындағы жауакершілік жүгі, алфавит мәні, сауатсыздық мәселесін өткір көтерді.

Атап айтар жәйт: жоғарыда еске алған Ч.Д. Жаныбековтың «Касым Тыныстанов: жизнь и творчество» атты зерттеу еңбегінде танымал тұлғаның қайраткерлік қырлары, талайлы тағдырымен қатар, ақын-ағартушы, ғалымқаламгер, аудармашы-драматургтігі кең орын алады. Сонымен бірге, әрине мәдени-ағарту ісіне, әсіресе жаңа алфавит жасау жолындағы жанкешті әрекеті мен жауапкершілік жүгін, туған тілдің грамматикасы мен әдеби тілдің негізін қалағанын кең түрде сөз етіледі. Бұдан басқа, Қырғызстандағы мәдени құрылысты дамыту мен нығайтуға, ұлттық мұражай мен ғылыми кітапхананы, музыкалық-драмалық театр өнерін ұйымдастыру ісіне белсене қатысқаны да алуан ізденіс, дереккөздері мен мұрағаттық мате- 
риалдар арқылы жан-жақты ашылады. Елдік мүдде, дәстүр тағылымы, руханият өрісі терең қозғалады.

Сондай-ақ, бірқатар оқулық пен оқу құралдарын жазды: Оку кітабы (1924), Үлкендерге арналған әліппе (1926), Ана тіліміз (1927), Тіл сабағы (1932), Қырғыз тілінің морфологиясы (1934), Қырғыз тілінің синтаксисі (1936) т.т. Негізгісі, ел тарихы мен руханиятына сүбелі үлес қосты. Қырғыз грамматикасы мен әдеби тілінің негізін қалайды (Жаныбеков, 2003:211).

Біздіңше, Қ. Тыныстанов туралы аталмыш еңбек ізденіс арнасы кең, мұрағаттық материалы мол, қоғамдық құбылыстар мен кезең көріністері әр қырынан ашылғандықтан, танытқыштық мәні зор, біліми-ғылыми сипаты айқын, мәденирухани тағылымы бағалы зерттеулердің қатарына жатады.

Бастысы, айрықша атап өтер болсақ, Қ. Тыныстанов РКП (б) обкомы коллегисында «Манас» эпосы жөнінде жасаған баяндамасында (1925), кейінгі кезекте «Манас» эпосына қатысты алғашқы Бүкілодақтық конференцияға қатысып, онда тарихи туындының тақырыптық-идеялық бағытын, жанрлық жүйелер мен көркемдікэстетикалық құндылықтарын айқындап, манастану мәселесінің өткір де өзекті тұстарына назар аударады $(1935,27-28$ желтоқсан). Бұдан басқа, аталмыш маңызды басқосуда профессор Е.Д. Поливанов, қазақ қаламгері М.О. Әуезов баяндама жасайды.

Еске алсақ, М. Әуезов өз кезегінде - «Әр жылдар ойлары» (1959), «Уақыт және әдебиет» (1962) атты еңбектерінде, атап айтқанда «Қырғыздың батырлық эпосы «Манас», «Манас» эпосының халықтық нұсқасын жасау керек» (Фрунзе қаласында «Манас» эпосын зерттеу жайындағы конференцияда сөйлеген сөз - 1952 жыл, 8 шілде) жан-жақты көрініс тапты (Әуезов, 1969:478). Әсіресе, аталған мақала, зерттеулер жүйесінде - «Манас» мәселесін, «Манастану» тарихын кең түрде сөз етеді. Алғашқы тұстары жырдың пайда болуы мен оның тарауы, насихатталуы мен даму үдерістеріне, ондағы жомықшылардың орынүлесі, типологиялық һәм поэтика мәселелеріне мән береді. Сондай-ақ, эпостың орындаушылары - Сағымбай Оразбақов пен Саяқбай Қаралаевтың жыршылық-орындаушылық қабілет-мүмкіндіктері, жырдың тақырыптық ерекшеліктері, құрылымдық жүйесі, идеялық мәні, көпнұсқалығы һәм көпқабаттылығы мен заңдылық-шарттары, эпикалық орта мен халықтық сипаттар, генезистік жүйе мен дәстүрлілік арқау, өмір өрімі, идеялық-тақырыптық һәм көркемдік қырлары кеңінен көрсетіледі. Эпос мәні, табиғаты мен тарихы, тағылымы сөз болады.

Анығында, M. Әуезовтің «Қырғыздың батырлық эпосы «Манас» атты зерттеу еңбегінде - «Манасты» айтушылардың алдыңғы қатарында - Келдібек, Балық, Найманбай, Ақылбек, Тыныбек орны мен үлесі кеңінен көрсетіледі. Ал, Сағымбай, Қаралаев нұсқасы, оның тақырыптық мәні, ерекшелігі де кең түрде сөз болады. Туынды табиғаты, аңыздық-мифтік жәйттер, оқиға желісі, көркемдік өрнектер, синтақсистік айшықтар, сөздік құрамы, поэтикалық тәсілдер, қысқасы архитектоникасына мән беріледі. Орайлы тұста: «...Қай нұсқасын алып қарасақ та, эпостың негізі элементтерінен бұл жыр о баста халықтың туындысы екенін, оны ру коллективінің мақсаты мен тілегін білдірген жыршылар шығарғанын анық көреміз. Батырлық хикаяны тудырған да, өз ішінен шыққан өкілдердің, яғни батырлардың жинақты бейнелерін жасаған да -халық» десе (Әуезов, 1969 :111), келесі кезекте: «... «Манасты» тұтас күйінде бір кісі ғана шығармаған. Ол сан ғасыр бойына, сан буын жомықшылардың қатысуымен ұлғайып, дамып отырған. Тіпті бір ақынның өзі де туындысын бір сәтте аз уақыттың ішінде шығара салмаған. Белгілі бір тыңдаушылардың алдында жырлайтын болғандықтан ол ақындық қуаты мен қиялы жеткенше жаңа оқиғалар, жаңа эпизодтар ойлап тауып отырған. Ал қиял өрісі тарылып, шабыты сарқылғанда ол жырлауды аз уақытқа, кейде айлап, жылдап доғара тұрып дастанның желісін ұлғайтумен, жаңа эпизодтар енгізумен болған», - деп жазады (Әуезов, 1969:112). Осының негізінде автор дастанның мазмұны мен формасына, жорықтар жайына, сюжеттік желіге, ерлік сипаттарына, баяндау мотивтері мен циклдар сырына мән береді. Бұдан өзге, ас тақырыбы, ат жарысы мен балуан күресі, Манас пен Қаныкей қатнасы, өз ара құрметтері де нақты да нанымды өріс алады. Қоғамдық жағдай, кезең көріністері, өмір ағынына мән беріледі.

Зерттеу жүйесінен, дастандағы қаһармандар бейнесі, ондағы басты бейне - Манастың батырлық-тұлғалық ерлік-қимылдары, жорықұрыстардағы әрекеті мен монологтары, портреттік сипаттары әсерлі, мәнді беріледі. Бұдан басқа, Манастың ортасы мен отбасы, достық және туыстық қарым-қатнастары, тіпті батырдың аты - Аққұла сипаты да тиісінше сөз етіледі. Ал, Манас төңірегіндегі батырлар - Шуақ пен Сырғақ хандардан - Көкше мен Жаңбыршы елдік, ерлік қасиеттерімен ерекшеленеді. Дастандағы 
қалмақтар мен қытай жұрты, зорлықшыл топ өкілдері - Қоңырбай, Дөкір, Жолой да өз орындарында көрініп, әрекет-қимылдары мен айлатәсілдері мол бейнелер ретінде есте қалады. Автор дастан табиғатына еркін еніп, дәуір дидарын, өмір өрімін, адамдар әрекетін, олардың ортасын кең түрде ашады. Уақыт пен кеңістікке мән беріледі.

Зерттеудің салмақты бөлігін - «Манастың» сөздік-поэтикалық тәсілдері» құрайды. Мұнда, әсіресе Сағымбай айтуындағы мәтін құбылысы, баяндау мәнері, әсіресе ондағы қисынсыз көрініс, сәтсіз суреттеулер, негізсіз қайталаулар, әр жырдың бастауы мен оқиғалар желісі, жанама эпизодтар тізбегі кеңінен қамтылып, мән-маңызы өріс-өрнегі сын тұрғысынан еске алынады.

Ал, дастандағы өлеңдік ерекшеліктер , аллитерация мен ассонанстың басым сипат алуы, мазмұн мен формада, басталуы мен аяқталу сәттерінде, жер-су, ру-тайпа атаулары, табиғат құбылысы, жануарлар дүниесі т.с.с. әуезділік, өз ара үйлесімділік мәні назар аудартады. Сондайақ, дастан жүйесінен танылатын - стилистикалық ерекшелік, архайизм мен варваризмдер, комизм үлгілері, қысқасы авторлық өнер өрімі кең орын алады. Оның кейбір тұстарын автор былай қорытады: «...дастанның өзіндік ерекшеліктерінен туатын аса зор, түбегейлі бір мәселе, ең болмаса талданып отырған бір нұсқаның авторлары жайындағы мәселе мүлдем шешілмей қалып отыр. Бір жағынан дастанның ұлғайып өсуінде, оның сюжеттік құрылысында талай-талай автордың еңбегі бар екендігі даусыз. Екіншіден, аталған жәйттердің бәр-бәрін негізгі ойға бағындырып, нұсқаға белгілі дәрежеде біртұтас сипат берген бейнебір редактор тәрізді соңғы жыршының творчестволық зор іс тындырғаны да айқын көрінеді. Дастанның формасын бұдан әрі зерттегенде сөздік стильді, сөз құрамын, ұйқасты, синтақсистік айшықтарды талдауға, сөйтіп соңғы айтушының және оның алдындағы жыршылардың авторлық өнерін ашуға көңіл бөлінуі шарт. Бұл міндетті маман фольклористердің, әсіресе қырғыздан шыққан ғалымдардың бірлесе, тізе қоса еңбек етуі арқылы ғана шешуге болады. Өйткені, ана тілінің рухы басқалардан гөрі олардың өздеріне әлдеқайда түсінікті де жақын» (Әуезов, 1969:163).

Ал, «Манас» эпосының халықтық нұсқасын жасау керек» атты келесі зерттеуде атақты дастанның әр ел халықтарының фольклоры мен эпосы арасында оқшау тұрғаны, оны зерттеудің міндеттері мен жинақтау-жариялау жолдарын айқындау қажеттілігі кеңінен көрсетіледі. Зерттеу жүйесіне қатысты: «...Мен 30 жылдардың басында «Манасты» зерттеуге кірістім де, 1935 жылға дейін өз зерттеуімнің алғашқы нұсқасын тәмамдадым, ал 1937 жылы жөндеп шықтым. 1942-1943 жылдары мұнда мен жоқта оны біреулер үстінен қарапты. Бірақ, 1944 жылы мен өзім тағы өңдедім де, тіл және әдебиет институтына тапсырдым. Осы еңбектің негізінде жазылып, газеттерде жарияланған кейбір мақалалар болмаса, ол тұтас қалпында әлі жарық көрген емес. Оның үстіне сол кезде, яғни отызыншы жылдардың бас кезі мен орта шенінде «Манастың» Сағымбай нұсқасынан басқа варианты болған емес. Қаралаев варианты 1936 жылы жазылып, алына бастады. Мен сол жазылып бітпеген нұсқаны оқыдым. Ал, Молдабасанды тыңдап көрдім, бірақ оқыған емеспін», - деп жазады (Әуезов, 1969:165).

Орайлы тұста, қырғыз халқына «Манас» эпосы керек пе, әлде жоқ па? деген сұрақтар төңірегінде ізденістер жасап, оның қажеттілігін әр қырынан ашып, талдау-салыстырулар жасайды. Нәтижесінде: «Манас» кітап болып басылуға, зерттелуге тиіс», - деген қорытынды жасайды. Автор ол үшін, әрине әр алуан нұсқалар мен оның ерекшелігіне ден қояды. Ондағы ел-жер тағдыры, табиғат құбылысы, авторлық һәм образдық жүйеге, эпикалық баяндауға, оқиға желісі мен қайталаулар мәніне, поэтикалық-стильдік белгі мен айырмашылықтарға, портреттік сипаттамаларға, ерлік-өрлік қимылдарға, мораль мен дін арақатнасына, наным-сенім, қияли мезеттерге, комедиялық ситуацияларға, ой-сөз жүйесіне, басқа да қырларына назар аударылады.

\section{Нәтиже}

Жинақтап айтқанда, М. Әуезовтің «Қырғыздың батырлық эпосы - «Манас» (19361959), «Манас» эпосының халықтық нұсқасын жасау керек» (1959) атты зерттеу мақалалары әр жылдар ізденісі мен нәтижесін, біліми-ғылыми аспектілерді, бастысы атақты дастанның табиғаты мен тағылымын, жанр жүйесі мен көркемдік арналарын, мәтін құбылысын, тілдікстильдік сипаттарын салыстыру-талдау арқылы қоғамдық жәйттерге, кезең көріністеріне қатысты кемел ойлар айтып, өзекті де өткір мәселелерді кеңінен қозғайды.

Бұдан басқа, әсіресе: «М. Әуезовтің «Манас» жөніндегі дискуссияға араласып, ең беделді, шешуші сөз айтуы оның ғылыми мүддені ардақ тұтқаны ғана емес, халықтар достығының 
нығаюына да қосқан үлесі болды» (Бердібаев, 1989: 356).

Әдебиеттанушы-ғалым Р. Бердібаев «Шоқан шарапаты» атты мақаласында: «...Қазақ ғалымының қырғыз фольклорына арналған еңбегінің ең маңыздысы - «Манас» эпосының бір бөлігін жазып алуы, оны орыс тіліне аударып, сол замандағы ғылым назарына ұсынуы. Ғалым бұл жырдың құрамын, мазмұнын, көркемдік ерекшеліктерін терең түсініп қана қоймай, күні бүгінге дейін бағасын жоймаған тамаша талдаулар жасаған...

Шоқанның «Манас» жайындағы айтқан пікірлері фольклортану тарихында тұңғыш қымбат тексеру болып табылады» (Бердібаев, 1989: 311).

Бұл бағыт, ізденіс арнасы мен зерттеу жүйесі журналист-қаламгер Ж. Бейсенбайұлының «Шоқан» атты ғұмырнамалық-деректі хикаятында жаңа бағыт, кең өріспен тереңдей түседі (Бейсенбайұлы, 2009:608).

Әдебиетші-ғалым Т. Жұртбай М. Әуезовтің «Манас» эпосының тарихилығы мен халықтығы төңірегіндегі 1951-1953 жылдардағы Бүкілодақтық көлемдегі талқы тұсындағы: Қырғаз халқына «Манас» керек пе, жоқ па? - деген ортақ сауалға қатысты адами әрекетқимылдары, біліми-ғылыми ұстанымы, мәтіндік мәні мен нұсқаларына, аудармасы мен жариялануына сүбелі үлесі, батылдық пен жауапкершілік жүгін терең танытқанын кең түрде көрсетті. Түйінді тұста: «...Мұхтар Әуезовтің «Манас» эпосының тағдырын шешкен осы еңбегінің өзіақ оның есімін әлемдік руханият тарихында мәңгі қалдыруға толық татитын ерлікке парапар оқшау оқиға еді», - деп жазды (Жұртбай, 2011:225).

Асылы, осы жәйттерді ескерген тұста, әрине қазақ-қырғыз халықтары, тарихы мен тағдыры төңірегінде арғы-бергі кезеңдерге бірқатар барлау-талдау, қысқа шолу жасасақ, ортақ та үндес, сабақтас сипатты мәнді де мағыналы сырлар көп-ақ. Еске түсірсек, бұл ретте: « Ауылы аралас, қойы қоралас жатқан, ежелден еншісі бөлінбеген, әдет-ғұрпы, салт-санасы, тіпті тағдыр-талайы да ұқсас қазақ пен қырғыз халқының әдеби байланыстары да түп тереңнен бастау алатыны да бәсенеден белгілі. «Манас»пен «Алпамыс» дастандарынан басталып, Сүйінбай, Дулат, Мұрат, Құлманбет, Шортанбайлар мен Қатаған, Қалығұл, Арыстанбек, Нұрмолда, Молда Қылыш жырларымен астасып, Абай мен Тоқтағұлдармен жалғасып, Мұхтар Әуезов пен Шыңғыс Айтматовтарға ұласқан достық һәм бауырластық әдеби байланыстардың дәстүр жалғастығы бүгінгі күнге дейін ешбір үзілген жоқ» (Жайлыбай, 2018:3).

Анығында, қазақ-қырғыз халықтары арасындағы арыдан бастау алатын асыл арна жекелеген тұлғалар арқылы да жарасымды жалғасын тапты. Ойға алсақ: «Бұл байланыстың басталуына көрнекті тұлға Мұхтар Әуезовтің көреген көсемдігін, болжампаз даналығын сол кездегі «бала» Шыңғыстың шығармасына зер салып бағалауынан аңғаруға болады. Екі заңғардыңбілімпаздығыменбиікөресін,үндескен сәтін тарихи «Манас» дастанының төңірегіндегі төккен терлерінен де тануға болады. Айтматов пен Әуезовтің бауырластық байланысы қырғыз бен қазақтың қарым-қатнастарын алға ілгерілетті және ұрпаққа айтарлықтай сабақ болып, дәстүр қалыптастырды» (Рысқұл, 2018:5).

Сонымен бірге, Жұмағұл Сааданбековтың «Шыңғыс Айтматовтың философиясы» атты еңбегінде Ш.Айтматов пен қырғыз халқы хақында кеңінен тоқталып, атақты қаламгердің дүниетанымы мен шығармашылық мұрасы, әлемдік деңгейдегі даңқты тұғыры туралы жан-жақты сөз етеді [16.184]. Әсіресе, Ш. Айтматовтың қырғыз алқының атақты «Манас» эпосына қатысты көзқарасын, азаматтық берік ұстанымын кең көлемде ашады.

Орайлы тұста, ақын А.Токомбаевтың «Манас» туралы Қырғыз КП ОК Хатшыларына жолдаған хатын, ондағы коммунистік талаптарды, сталиндік куғын-сүргін кезеңді, қоғамдық санадағы әр қилы ұстанымдарды кең түрде көрсетеді. Кітапта берілген Хат мәтіні, «Токомбаевқа жауап» сынды материалда - «Манас» эпосы, оны айтушы С.Орозбаков есімі мен еңбегі теріске шығарылады. Тіпті: Манас - «ұлтшыл», эпосты айтушылар - «ұлтшылдар» аталады. «Манасқа» қатысты: әуежай, кинотеатр, канал, ұжымшар, аудан, алаң, кешен, т.т. орын алғаны да тілге тиек етіледі. Өз кезегінде: «Айтматов республика ішіндегі этноұлттық қарым-қатынастың тым саясаттанып кеткеніне тым мазасыздық пен алаңдаушылық танытты. Ол қоғамда саяси тұрақтылық пен сенімділік және достық атмосфераны дамытуда басты ұлт ретінде қырғыз халқына үлкен жауапкершілік жүктелетінін білді. Ош оқиғасы кезінде ол сол жерге барып, қырғыздың жергілікті этноұлттық элитасына барлық кінәні артты. Бұл, өкінішке орай, солардың жауапкершілік сезімін оятқан жоқ, керісінше, реніш пен түсінбестік туғызды.

Шыңғыс Айтматов бірнеше рет өз сөзінде кітаптың, әдебиет пен өнердің, бұқаралық ақпарат 
құралдарының, әсіресе қырғыз тіліндегі, республикада тұтас азаматтық ұлт қалыптастырудағы жоғары рөлін атап көрсетті. Өз халқының тарихын жетік зерттегендіктен, ол осыны талап етті» (Сааданбеков, 2018:120). Қоғамдағы еуразиялық концепция, еуропалық модель, посткеңістік интеграция жөніндегі көзқарастары да жаһандық әлемдегі басты позициялармен үндестік табады. Осы жайларды назарға алсақ, Ш. Айтматовтың дүниетанымы мен шығармашылық мұрасында қырғыз халқы, оның руханияты, елдің арғыбергі кезеңін терең танытатын басты туындысы - «Манас» эпосы тақырыптық ерекшелігімен, мазмұн жүйесімен, оқиғалық өрімі мен даму желісімен, тарих пен тағдырлар талқысын шынайы шындықтар арқылы көрсеткен мәнді қырларымен, кезеңдік құбылыстарды әр тұсынан алып, айқын танытқан маңызды сипаттарымен, баяндау мәнері, жеткізу жолдары әсерлі һәм тартымды әрі қызғылықты оқылып, рухани-тәлімдік сыр-сипаттарымен, танымдықтағылымдық белгі-бедерімен, көркемдік нәрімен айрықша болып табылады.

Асылы, сөз арқауы - «Манас» эпосы хақында болғандықтан, Қырғызстанның астанасы - Бішкекте Халықаралық Түркі академиясы жарыққа шығарған «Манас» эпосының таныстырылымы өтті (Кітап көлемі - 650 бет). Бішкектегі гуманитарлық университет ұжымы ұйымдастырған - «Манас»эпосының таныстырылымы бірнеше қырынан назар аудартқан еді.

\section{Қорытынды}

Алдымен, қалың көпшілікке бұрыннан белгілі манасшы Медер Мергенбаевтан жеткен қолжазба жан-жақты жинақталып, тиянақты дайындалған-ды. Келесі кезекте, араб графикасындағы қолжазба нұсқа бұрын басылмаған әрі тақырыптық мәні, мәтін мазмұны, оқиға өрімі, тілдік-стильдік ерекшеліктер жүйесі де қалың оқырман ойын қозғап, әдебирухани талап- тілектерге толық жауап берері хақ. Анығында, М. Мергенбаев қырғыз халқына кеңінен таныс, әрі белгілі манасшылар қатарына кіреді. Ел руханиятына сүбелі үлес қосқан С. Орозбақов, С. Қаралаев, Тоғолоқ Молдо т.б. атақты манасшы-эпосшылармен берік байланыс орнатып, әр алуан нұсқаларын естіп-үйреніп, жазып та алады. Бастысы, латын әліпбиімен қырғыз тілінде тұңғыш рет жарық көрген ғылыми басылымдар қатарына жатады. Демек, «Манас» эпосы әлемдік даңқы зор, әрі түркі халықтары арасында руханият өрісін, көркемдік көкжиегін кеңейткен, білім-ғылым мәнін арттырып, биік бел-белестерге көтерген қымбат қазына әрі әлем жұртшылығына, түркі халықтарына аса мәшһүр туындылардың бірі. «Манас» эпосының әлемдік даңқы мен руханият өрісіндегі танымдық мәні, тағылымдық тағылымдық қыры осы жәйттерден анық-қанық аңғарылады.

Бұдан басқа, кейінгі кезеңдерде ақынайтыскер, қаламгер Б. Әлімжановтың «Манас» эпосының 1000 жылдығы тұсындағы ҚазақстанҚырғызстан ақындарының айтысында (мысалы, О. Құтманалиев, А. Нұрғалиев, Ә. Айталиев т.б.) қазақ-қырғыз халықтарының достығы, арғы-бергі тарихтағы қарым-қатнасы хақындағы ойлары мен толғамдарының мәні зор (Сааданбеков, 2018:324). Әрі ақын-айтыскер Б.Әлімжанов «Манас» эпосын алқалы жиындар мен мәденирухани шаралар тұсында ауызша айтып, кең көлемде насихаттап, жан-жақты таныстырыптүсіндіріп келе жатқаны да елдік-ерлік рухты асқақтатудың, отансүйгіштік пен патриотизмнің нақты мысал-дерек, үлгілі үрдістердің бірі (мысалы, ҚРҰлттық академиялық кітапхана, Ұлттық музей, Л.Н. Гумилев атындағы Еуразия ұлттық университеті, 2-4 Еуразиялық халықаралық кітап көрме-жәрмеңкесі т.с.с. арнаулы орындарда әлденеше рет туынды табиғатына терең еніп, көңіл толқындары мен жан-жүректің тебіреністербелістерін емен-жарқын көпшілік алдында жүйелі жеткізген-ді).

Бұдан байқалатыны, «Манас» эпосы халықтық мұраның, ақындық өнердің озық та үздік үлгісі екеніне көз жетеді. Оның үстіне, «Манас» эпосы елдік пен ерлік шежіресі. Ал, табиғаты мен тағылымы, көлемі мен көркемдігі, мазмұн желісі мен мәтін құбылысы, батырлық әрекеттер, әр қилы жорық-шайқастар, Көкетай асы, Алмамбет, Қаныкей орны, қаһарманның әрекет-қимылдары, әдеби-рухани әлемі, болмыс бедері, уақыт рухы, тіл мүмкіндіктері мен стильдік айшық-нақыштар да табиғи өріс алып, жинақы да жатық, жүйелі жеткізіледі.

Қырғыз халқының атақты «Манас» эпосын айтушылар мен оны әр алуан нұсқасында жырлап - жеткізген, насихаттаушылар мектебінің де алар орны, үлес-салмағы орасан зор. Жыр мен жыршылық өнер заңдылықтары, жомықшылар қызметі де мәнді орын алады. Манасшылардың көпқырлы қасиеттері, орындаушылық һәм жыршылық сынды өнерпаздық сипаттары мен шығармашылық әлеуеті де назар аударуға тұрады. Бұл ретте, сөз жоқ эпостың танымал орындаушылары - Сағымбай Оразбақов пен Саяқбай Қаралаевтың еңбектері ерен. Өз 
кезегінде М. Әуезов «Манас» эпосын айтушылар мектебін анықтаған тұста - Нарын мен Қаракөл (Пржевальск) мәнін кең түрде ашады. Әрі осы екі мектептің ірі де көрнекті өкілдері ретінде С. Оразбақов пен С. Қаралаевтың есімі мен еңбегін, жыршылық-орындаушылық қырларын, мәнді қасиеттерін, ұлт руханиятындағы ересен үлесін де орынды атап көрсетеді.

Жинақтап айтқанда, Түркі әлемі мен «Манас» эпосының ортақ мұраттарынан, қазаққырғыз әдебиетінің тамырлы тарихынан арғы- бергі кезеңдердегі қарым-қатынас, басым бағыттар мен байланыс арналары кең орын алады. Ал, руханият өрісінен - «Манас» эпосының тарихы, зерттелуі мен жариялану жайы, ортақ мұраттар тоғысынан талайлы тағдыр, оның ішінде М. Әуезовтің елдік-ерлік ұстанымдары, біліми-ғылыми қырлары, жанкештілігі мен жауапкершілік жүгі, ақыл-парасаты, зерттеу жүйесі, көркемдік арналар, өз ара әсер-ықпалы да терең көрініс береді. Мұның қазір де мәнмаңызы зор.

\section{Әдебиеттер}

Ақаев А. Қырғыз мемлекеттігі және «Манас» халық эпосы. - Астана: Күлтегін, 2003. - Б. 229, 237.

Әлімжанов Б. Шығармалары. 6-том. - Көкшетау: Келешек, 2016. - 324 б.

Әуезов М. 12 томдық шығармалар жинағы. 11 - том. - Алматы: Жазушы, 1969. - 478 б.

Бердібаев Р. Кәусар бұлақ. - Алматы: Жазушы, 1989. - 356 б.

Бейсенбайұлы Ж. Шоқан. - Алматы: Қазақстан, 2009. - 608 б.

Дәдебаев Ж. Менің университетім. - Алматы: Қазақ университеті, 2007. - Б. 135,141.

Жұртбай Т. Ұраным - Алаш!.. 3-том. - Алматы: Ел-шежіре, 2011. - 225 б.

Жайлыбай Ғ. Тағдыры ұқсас, тамыры терең // Жұлдыз. -2018. - №11. - Б. 3

Жаныбеков. Ч. Д Касым Тыныстанов: жизнь и творчество. - Бішкек: Биіктік, 2003. - 292 с.

Жолдасбеков М. Асыл арналар. - Алматы: Жазушы, 1990. - 294 б.

Ибраимов О. Айтматов последний писатель империи. Жизнь и творчество. - Астана: Ғылым, 2018. - 282 б.

Қазақ фольклористикасының тарихы. - Алматы: Ғылым, 1988. - Б. 66-67.

Қазақ фолклористикасы. - Алматы: Ғылым, 1972. - 298 б.

Қазақ фольклорының типологиясы. - Алматы: Ғылым, 1981. - 23 б.

Рысқұл А. Шығыстың жарық жұлдызы - Шыңғыс Айтматов // Жұлдыз. -2018. - №11. - Б. 5.

Сааданбеков Ж. Шыңғыс Айтматовтың философиясы. - Астана: Basprint, 2018. - 184 б.

Валиханов Ч. Собран. соч. Т. 1 - 367 б.

\section{References}

Akaev A. (2009) Kyrgyz Statehood and Manas Folk Epos. Astana: Kultegin, 2003. P. 229-237. (In Kazakh)

Alimzhanov B. (2016). Works. Volume 6. Kokshetau: The Future, 2016. 324 p. (In Kazakh)

Auezov Collection of 12 volumes. Volume 11. Almaty: Writer, 1969. 478 p. (In Kazakh)

Berdybaev R.(1989). Kausar Spring. Almaty: Writer, 1989. 356 p. (In Kazakh)

Beisenbayuly Zh. Shokan. (2009) Almaty: Kazakhstan, 2009. 608 p. (In Kazakh)

Dadebaev Zh. (2007) Menin Unïversitetim. Almatı: Qazaq unïversiteti, 2007. P. 135,141.

Ibraimov O. (2018). Aytmatov posledniy pisatel' imperii. Zhizn' i tvorchestvo. Astana: Ġylym, 2018. 282 p. (IN RUSSIAN)

Jaylıbay Ğ. (2018).Tağdırı uqsas, tamırı tereñ. Juldız, 2018, №11. P. 3. (In Kazakh)

Joldasbekov M.(1990). Asıl arnalar. Almat1: Jazush1, 1990. 294 p. (In Kazakh)

Jurtbay T. (2011). Uranım-Alaş!.. 3-tom. Almatı: El-shejire, 2011. 225 p. (In Kazakh)

Janıbekov. Ç. D (2003). Kasım Tinıstanov: Jizn i tvorchestvo. Bískek: Biíktík, 2003. 292 p. (In Kazakh)

Kazakh Folklore Historiography. (1972) Almaty: Gylym, 298 p. (In Kazakh)

Typology of Kazakh folklore. (1981) Almaty: Gylym,, 1981. P. 23. (In Kazakh)

Risqul A. (2018).Şığıstıñ jarıq juldızı. Şıñ̆ğıs Aytmatov. Juldız, 2018, № 11. P. 5. (In Kazakh)

Saadanbekov J. (2018). Chingis Aytmatovtın filosofiyası. Astana: Basprint, 2018. 184 p. (In Kazakh)

Valikhanov Ch.Ch. Collected works in five volumes. Volume 1, $367 \mathrm{p}$. 